\title{
On Current Situation and Trend of Tourist Hotel Operating Management in China
}

\author{
Peifeng Zhu \\ Shandong Vocational College of Tourism, Ji'nan Shandong, 250200, China
}

Keywords: Tourist hotel; Operating management; Development trend.

\begin{abstract}
As tourist industry has developed rapidly in recent years, the proportion of tourist hotels in Chinese tourist industry increases gradually. The number of high-star tourist hotels increases stably. International major brands expand by a large margin in Chinese tourist industry, which generates certain influence on operating management of tourist hotels in China. This paper starts from current situation of operating management of tourist hotels in, explores future development trend and proposes corresponding development measures, in the hope of correctly guiding development of tourist hotels.
\end{abstract}

\section{Introduction}

As socialist market economy further develops, tourism-related enterprises also present obvious knowledge-based and information-based development trend. Under such social background, operating management activity of tourist enterprises becomes am important factor which influences sustainable and healthy development of tourist enterprises and also becomes the power source of modern tourist enterprises to gain corresponding competitive edge in market competition. Hence, it occupies the core position in formulation of enterprise development strategy. The tourist hotel as an important tourist enterprise should closely follow the trend of era and gain better development. To win in the fierce market competition, it is required to enhance operating management, improve comprehensive strength through scientific operating management and strive to gain better development in future.

\section{Problems in tourist hotel operating management}

As tourist industry develops rapidly, industry scale of tourist hotels also extends greatly. Industrial quality presents obvious rising development trend. Industrial influence furthers strengthens in tourist industry. But it is undeniable that some problems exist in tourist hotel operating management. For example, the investment in the hotel increases, but the operating efficiency presents downtrend; high-star and low-star hotels develop in an unbalanced way; the attention to international brands is far higher than that of Chinese brands; with booming development of the industry, employees' remuneration competitiveness gradually declines; guests require to gradually improve, but hotel service quality is still poor. The series of problems generate serious bad effects on sustainable and healthy development of tourist hotels. Next, this paper makes detailed analysis as follows.

\section{The increasing quantity of high-star and low-star hotels is unbalanced.}

Star-grade hotels have been the mainstream of accommodation demand of tourist industry and has certain guiding function for main development direction of tourist hotel market. As tourist industry continues to develop, the total scale of star-grade hotels in China has risen gradually in recent years. But the development of high-star hotels is far higher than that of low-star hotels. Average growth rate of high-star hotels once exceeded $10 \%$ on the average. The development trend is swift and violent. However, the development of low-star hotels is relatively slow. The growth rate of two-star hotels is less than $10 \%$. One-star hotels do not increase. On the contrary, one-star hotels show a downtrend. Such unbalanced development imposes adverse effects on sustainable and healthy development of tourist hotel industry ${ }^{[1]}$. The cause for such phenomenon is that in developed tourist region, low-star 
hotels lack enthusiasm in star grade declaration due to the shortage of competitive edge. Some low-star hotels fail to establish distinct corporate image in the market due to the lack of scientific positioning, and their operating management benefit is relatively poor. These greatly give rise to unbalanced increasing of high-star and low-star hotels, and seriously restrict sustainable and healthy development of tourist hotel industry.

Tourist hotel industry flourishes, but employee's compensation competitive capacity declines.

In recent years, the development of tourist hotel industry has receives extensive attention from all sectors of society and even once became the hotspot of investment and the issue concerned by medial departments. Obvious booming development trend is shown. But, as tourist hotel industry flourishes, employee's compensation competitive capacity declines. High-quality hotel management talents leave gradually, which has become a major factor which restricts stable development of this industry. In current situation, tourist hotels generally invest less in talent training. They pay attention to talent mining, but ignores talent training. Besides, their strategy of attracting talents is not sound. Finally, a large number of excellent management talents leave, which generates serious poor influence on optimizing hotel operating management and improving service quality.

\section{Customers require to further improve, but hotel service quality presents a downtrend.}

Service quality is a precondition for service industry to develop. To occupy a position in fierce market, tourist hotels must combine customers' actual needs and continuously improve service quality. In the new period, as the society further improves and the development trend of economic globalization intensifies, the vision field of the public becomes wider, and their accommodation experience also increases. Thus, higher requirements are put forward for hotel service quality. This generates certain influence on implementation of hotel operating management activity. However, in actual hotel management process, some hotels lack uniform service standards, and the inspection department does not pay sufficient attention to inspection work. Thus, the service level of some hotels is low. Even some hotels relax management after star grade evaluation, and cannot reach star-grade service level. This imposes serious bad effects on the overall image of tourist hotel industry.

\section{Main development trend of tourist hotel industry in the new period}

\section{The growth rate of high-star tourist hotels slows down gradually.}

Since the adverse effects of financial crisis imposed on China's economic development gradually reduces in 2008, tourist industry has shown booming development trend, and tourist hotel industry also has developed. The number of high-star hotels increases gradually, and presents a increasing trend year by year. However, as the Party Central Committee put forward the proposition "diligence and thrift, opposition against extravagance and waste" according to China's national conditions in 2013, operating management pressure of high-star hotels increased sharply. Relevant survey shows the price of three-star hotels has been generally lower than that of four-star hotels in recent years, while operation revenue basically holds the line. This also generates certain influence on continuous development of high-star hotels. In addition, unbalance supply and demand still exist in tourist hotel market. The development trend of oversupply will further expand. Thus, tourist hotel market will inevitably face rational market regulation in the near future.

\section{Tourist hotel market presents diversified development.}

As “eight provisions” are issued by the Party Central Committee and implemented in tourist hotel industry, on the one hand, this policy makes high-star hotels have to innovate and transform in order to gain certain market competitiveness and win certain advantages in fierce market competitions. Under the influence of such policy, traditional high-star hotels which take government affair work as the subject must transfer their development path, continuously expand market and put more energy on development of mainstream business forms, such as transformation of mainstream business and taking business, convention and exhibition as the major development direction ${ }^{[2]}$. In current stage, business-type tourist hotels have gradually become the mainstream market business form in tourist 
hotel industry. Besides, influenced by industrial environment, business-type hotels will still keep a good development momentum in a long term. Especially under the background where domestic demand continuously expands, traditional hotels dominated by sightseeing service will transform to local consumption market. Hence, in future years, the income of tourist hotels in some second-tier and third-tier cities in terms of catering will certainly exceed the income from guest rooms, which generates certain influence on future development direction of tourist hotels. On the other hand, the implementation of "eight provisions" can bring certain development opportunity for middle-grade tourist hotels, and promote fast development of hotels providing relevant services for mass market by depending on capital market under the support of national policy. Moreover, luxury and competitive hotels which serve for niche market and can meet customers' individuation demand gain certain development under current social background. Their popularity improves gradually and they are approved by the masses.

\section{E-commerce has huge development potential.}

In operating management of tourist hotels, traditional channel is a main mode for hotels to carry out marketing work. The relevant investigations show that at present, Chinese tourist hotels highly depend on traditional marketing channel, which is 30\% higher than America. The dependence on traditional marketing channel and the low application rate of e-commerce direct marketing will inevitably imposes adverse effects on the income management of hotels. These even become major factors which restrict benign development of tourist hotel market ${ }^{[3]}$. Thus, as e-commerce further develops and is widely applied in all walks of life, tourist hotels in China will certainly enhance attention to e-commerce direct marketing and drive rational market integration of star-grade hotels and gain new development by e-commerce.

\section{Countermeasures on operating management optimization of tourist hotels}

\section{Further improve popularity of Chinese tourist hotel brand.}

In the new period, as economy improves and China's intermodal influence strengthens, tourist hotels in China will certainly enter a new development state under social general environment. Thus, tourist hotels should self-brand innovation carry out, occupy a position in terms, enhance cooperation with international brands, overall expand upstream and downstream service market, gain corresponding development opportunity in the new market by referring to foreign advanced experience and create conditions for future development in order to better develop. Besides, with the help of internet information technology advantage, it is required to fully mine public praise and evaluation information of internet users and provide sufficient data reference for enterprises to make market decisions. Tourist hotels can gain good development in future and drive overall progress of tourist industry only through enhancing brand building based on internet information, facilitating development of tourist hotels and gaining extensive approval of social group.

\section{Explore "blue ocean" in middle-end market.}

In recent years, in the development process of Chinese tourist industry and tourist hotel industry, traditional economical hotels and luxury hotels start to realize the potential of middle-end market and gradually march in the middle-end market. For example, "BTG" launched "Tangram" brand according to market demand; NARADA HOTEL GROUP also actively launched "Narada Boutique Hotel" brand, and ginned good development effect. It thus can be seen that middle-end market will certainly the "blue ocean" in future tourist hotel market ${ }^{[4]}$. In the aspect of price. The price of middle-end hotels is moderate and can meet audiences' pursuit of higher cost performance. In the aspect of products, successful middle-end hotels generally adopt theme-based, unit-based and differential marketing strategies, and the products have strong attraction for the audience group. For the functions, middle-end hotels abandon big and complete service mode of traditional hotels in the development process, and focus on development of core products. Thus, service quality and service characteristics stand out. Hence, they can gain obvious competitive edge in market competition, and generate certain positive effects on benign development of tourist hotels. 


\section{Actively create thorough e-commerce marketing platform.}

With the development of network information technology, e-marketing plays an increasingly important role in enterprise operating management. In e-marketing system, third-party network marketing channel can construct the complete service process which integrates search, preview, booking, payment, evaluation, un-subscription and after-sale service. For example, tourist hotels may expand their popularity and improve their brand value by the help of customer resources of Tuniu.com and ctrip.com etc. But, such e-commerce marketing lacks certain expertise. Thus, tourist hotels should cooperate with hotels in various regions and relevant network marketing platforms to construct more professional network marketing system and create good conditions for network marketing in order to gain certain advantage in market competition ${ }^{[5]}$. Meanwhile, as WeChat is extensively applied among the public, WeChat e-marketing gradually becomes a new marketing channel of tourist hotels. Therefore, in the new period, tourist hotels should enhance attention to WeChat marketing, further expand marketing channels, offer guarantee for orderly marketing work and gaining better development through improving marketing quality in the development process.

\section{Conclusion}

In conclusion, in the face of fierce market competition, tourist hotels must combine characteristics of the era and ever-changing service needs of audiences, optimize and adjust development direction, operating management philosophy and management strategy and make sure the development of tourist hotels adapt current economic environment in order to occupy certain development advantage. Besides, tourist hotels should meet individual needs of audiences, lay a foundation for future success and make contribute to further development of China's tourist industry.

\section{References}

[1] Xu Wenyan, Dai Li, Study on operation performance of Chinese tourist hotels and its influence factors - case study of input and output data of 50 star-grade hotels in tourist cities, Productivity Research, 2013(5):167-169.

[2] Ma Kailiang, Research on food and beverage operation mode of Chinese tourist hotels, Journal of Sichuan Higher Institute of Cuisine, 2013(2):35-38.

[3] Ma Kailiang, Exploration and practice of strategy transformation of Chinese tourist hotels - case of hotel catering, Journal of Sichuan Tourism University, 2014(1):42-45.

[4] Wang Li, Ming Qingzhong, Conception of current situation and development strategy of Chinese tourist hotel collectivization, Foreign Trade, 2013(1):69-70.

[5] Ma Xiaoling, Thought on sustainable development of tourist hotels under low-carbon perspective - case study of Wuyishan Hotel, Journal of Wuyi University, 2013,32(1):84-87. 